\title{
Common mental disorders and perinatal depressive symptoms: an integrative review
}

\author{
Transtorno mental comum e sintoma depressivo perinatal: revisão integrativa \\ Trastorno mental común y síntoma depresivo perinatal: revisión integrativa
}

'Universidade Federal do Acre. Cruzeiro do Sul, Acre, Brazil. "Universidade Federal de Pelotas. Pelotas, Rio Grande do Sul, Brazil. "'Universidade Federal de São Paulo. São Paulo, São Paulo, Brazil.

How to cite this article: Silva BP, Neves PAR, Mazzaia MC, Gabrielloni MC. Common mental disorders and perinatal depressive symptoms: an integrative review. Rev Bras Enferm. 2020;73(Suppl 1):e20190823. doi: http://dx.doi.org/10.1590/0034-7167-2019-0823

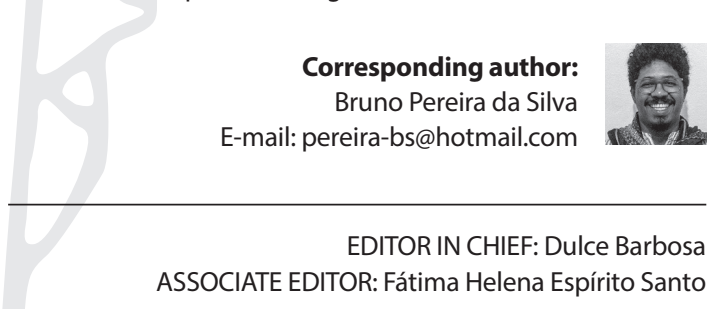

Submission: 11-21-2019

Approval: 06-26-2020

\begin{abstract}
Objective: to investigate occurrence and risk factors for common mental disorders and perinatal depressive symptoms. Methods: an integrative literature review using CINAHL, Embase, PubMed, PsycINFO, and LILACS, looking for studies conducted between 2014 and 2019. Data collection took place between June and July 2019. Health Sciences Descriptors (DeCS) and Medical Subject Heading (MeSH) were used in the search strategies employed in each database. Results: thirteen articles were included. Most studies were conducted in Brazil and with a cross-sectional design. The highest prevalence of common mental disorders (63\%) and depressive symptoms (30\%) were found in Brazilian studies. Conclusion: high frequencies were found for perinatal mental disorder, with emphasis on studies carried out in Brazil. Low socioeconomic status, being a single mother, history of mental disorder, unplanned pregnancy and multiparity were risk factors for the investigated disorders. Descriptors: Depression; Mental Disorders; Women's Health; Psychiatric Status Rating Scales; Review.
\end{abstract}

\section{RESUMO}

Objetivo: investigar a ocorrência e os fatores de risco ao transtorno mental comum e sintoma depressivo perinatal. Métodos: revisão integrativa da literatura, sendo utilizadas as bases de dados CINAHL, Embase, PubMed, PsycINFO e LILACS, buscando estudos conduzidos entre 2014 e 2019. A coleta de dados ocorreu entre junho e julho de 2019. Foram utilizados os Descritores em Ciências da Saúde (DeCS) e os Medical Subject Heading (MeSH) nas estratégias de busca empregadas em cada base de dados. Resultados: foram incluídos 13 artigos. A maioria dos estudos foi conduzido no Brasil e com delineamento transversal. As maiores prevalências de transtorno mental comum (63\%) e de sintoma depressivo (30\%) foram encontradas em estudos brasileiros. Conclusão: foram encontradas elevadas frequências para transtorno mental perinatal, com destaque para os estudos realizados no Brasil. Baixo nível socioeconômico, ser mãe solteira, história pregressa de transtorno mental, gravidez não planejada e multiparidade foram fatores de risco aos transtornos investigados.

Descritores: Sintomas Depressivos; Transtornos Mentais; Saúde da Mulher; Escalas de Graduação Psiquiátrica; Revisão.

\section{RESUMEN}

Objetivo: investigar la aparición y los factores de riesgo de trastorno mental común y síntoma depresivo perinatal. Métodos: revisión integral de la literatura, utilizando las bases de datos CINAHL, Embase, PubMed, PsycINFO y LILACS, buscando estudios realizados entre 2014 y 2019. La recopilación de datos se produjo entre junio y julio de 2019. Descriptores en Ciencia de Health (DeCS) y Medical Subject Heading (MeSH) en las estrategias de búsqueda utilizadas en cada base de datos. Resultados: se incluyeron 13 artículos. La mayoría de los estudios se realizaron en Brasil y con un diseño transversal. Las prevalencias más altas de trastorno mental común (63\%) y síntomas depresivos (30\%) se encontraron en estudios brasileños. Conclusión: se encontraron altas frecuencias para el trastorno mental perinatal, con énfasis en estudios realizados en Brasil. El bajo nivel socioeconómico, ser madre soltera, antecedentes previos de trastorno mental, embarazo no planificado y multiparidad fueron factores de riesgo para los trastornos investigados.

Descriptores: Depressión; Transtornos Mentales; Salud de la Mujer; Escalas de Valoración Psiquiátrica; Revisión. 


\section{INTRODUCTION}

Mental health problems affect the entire population, with some groups being more susceptible to a certain type of disorder. In this regard, women may present gender-specific disorders, such as mental disorders in perinatality ${ }^{(1)}$. During this period, from pregnancy to 12 months after delivery ${ }^{(2)}$, women-mothers are susceptible to the manifestation of common mental disorders (CMD). CMD are a suspected mental comorbidity for mood disorders, anxiety and somatization, characterized by depressive and anxious symptoms, such as lack of focus, forgetfulness, insomnia, fatigue, irritability, and non-specific somatic complaints. Attention is given to the aforementioned, as there is predominance of somatic to psychic complaints in individuals who manifest such disorders. Although the initial symptoms are not characterized aggressively, they can generate extreme dismay, and cause dysfunction in daily activities ${ }^{(3-4)}$. Specifically in the postpartum period, women are susceptible to non-psychotic depressive symptoms (DS) with dysphoric mood; psychomotor disorder; changes in sleep and appetite; fatigue; feeling of worthlessness or excessive guilt; recurring thoughts of death; suicidal ideation; feeling of inadequacy; and rejection of their baby ${ }^{(5-6)}$.

Perinatal mental health disorders have been studied in $90 \%$ of high-income countries and only in $10 \%$ of middle and lowincome countries ${ }^{(7)}$. During pregnancy, prevalence in high-income countries was estimated between $10 \%$ and $15 \%$; prevalence in middle and low-income countries was estimated between $10 \%$ and $41 \%$, depending on the location, the gestational trimester and the screening instrument used ${ }^{(7)}$. After birth, prevalence is estimated at between $24 \%$ to $27 \%$ for high-income countries and $14 \%$ to $50 \%$ in middle and low-income countries ${ }^{(7-8)}$. Studies in Brazil, carried out in Primary Health Care (PHC), found a prevalence between 30 and $40 \%$ and approximately $20 \%$ when performed with hospital or population-based samples ${ }^{(9)}$. Data from the "Nascer no Brazil" (freely translated as Born in Brazil) survey, the first Brazilian population-based hospital study that investigated maternal depression, points to a $26 \%$ prevalence of postpartum DS ${ }^{(10)}$.

Among the risk factors for CMD and DS in the perinatal period, the following stand out: adolescent pregnancy; being single or separated; unplanned pregnancy; lack of support in the marital relationship; previous stillbirth; repeated miscarriage; nulliparity; socioeconomic situation; lack of family support; pregnancy as a result of sexual violence ${ }^{(7)}$. There are behavioral difficulties of the partner (physical, psychological and verbal abuse, alcohol consumption, low education, unemployment, little assistance, and rejection of pregnancy); lack of trust in the partner; family agglomeration; depressive and anxious gestational symptoms; diseases during pregnancy; surgical delivery; multiparity; unstable childhood; childhood illnesses; babies' sex; lack of support network; history of psychiatric disorder; and other stressful life events ${ }^{(7,11)}$.

In this regard, estimating occurrence of disorders and identifying risk factors are fundamental steps to develop effective strategies for early detection, prevention, and care, updating nursing literature to identify potential gaps in knowledge about perinatal mental illnesses.

\section{OBJECTIVE}

To investigate occurrence and risk factors for common mental disorders and perinatal depressive symptoms.

\section{METHODS}

This is an integrative literature review (ILR), for which previously described methodological steps were followed to conduct this type of study ${ }^{(12)}$. In the first stage, PICo strategy (Population, Phenomenon of interest, and Context) was used to elaborate the guiding question, in addition to being a guide for data collection and information gathering ${ }^{(13)}$. Population $(P)$ included women in the perinatal period; Phenomenon of interest (I) represented occurrence of CMD and DS; and Context (Co) comprised the occurrence of phenomena globally in the last 5 years. Thus, the guiding question was: what is the occurrence of CMD and perinatal DS recently reported in national and international scientific literature?

To carry out the second stage, databases and descriptors to be used to execute the search strategies were defined. Health Sciences Descriptors (Descritores em Ciências da Saúde, abbreviated DeCS) and Medical Subject Headings (MeSH) were used to define the descriptors applied at CINAHL, Embase, PubMed, PsycINFO, and LILACS databases. In addition, Boolean operators AND and OR were used for the search. Chart 1 shows all search strategies used in each database. Search was conducted during July 2019, and the results were organized for screening on EndNote, with duplicate articles being excluded.

Chart 1 - Search strategies modulated according to each database (in English and Brazilian Portuguese), 2019

\begin{tabular}{|c|c|}
\hline Database & Search strategy \\
\hline CINAHL & $\begin{array}{l}\text { (((MH “Pregnancy") OR TI Pregnancy OR AB Pregnancy) OR ((MH } \\
\text { "Depression, Postpartum") ORTI ("postpartum depression" or } \\
\text { "postnatal depression" or ppd) OR AB ("postpartum depression" } \\
\text { or"postnatal depression" or ppd)) AND ("common mental } \\
\text { disorder"OR "common mental disorders")) }\end{array}$ \\
\hline Embase & $\begin{array}{l}\text { ("common mental disorder"/exp OR"common mental } \\
\text { disorder"OR"common mental disorders") AND ("postnatal } \\
\text { depression"/exp OR"pregnancy"/exp) AND [Embase]/lim }\end{array}$ \\
\hline LILACS & $\begin{array}{l}\text { tw: (("transtorno mental comum" OR "transtornos mentais } \\
\text { comuns" OR "common mental disorder" OR "common } \\
\text { mental disorders")) AND (instance:"regional") AND (mh: } \\
\text { ("Gravidez" OR "Depressão Pós-Parto") AND db: ("LILACS" OR } \\
\text { "BDENF" OR "INDEXPSI" OR "SMS-SP")) }\end{array}$ \\
\hline $\begin{array}{l}\text { PubMed/ } \\
\text { MEDLINE }\end{array}$ & $\begin{array}{l}\text { (("common mental disorder"OR"common mental } \\
\text { disorders")) AND (((“Pregnancy" [Mesh] OR“Pregnancy" } \\
\text { [tiab])) OR (“Depression, Postpartum" [Mesh] OR"Depression, } \\
\text { Postpartum" [tiab])) }\end{array}$ \\
\hline PsycINFO & $\begin{array}{l}\text { "COMMON MENTAL DISORDER" OR Any Field: "COMMON } \\
\text { MENTAL DISORDERS" AND (Any Field: PREGNANCY OR Any } \\
\text { Field:"POSTPARTUM DEPRESSION") }\end{array}$ \\
\hline
\end{tabular}

Observational, descriptive or analytical studies, of cross-sectional or cohort design, developed with women, published between 2014 and 2019 in English, Spanish or Brazilian Portuguese and that addressed occurrence of CMD or perinatal DS were included. Non-original articles (reviews) and other forms of publication that 
did not answer the guiding question and did not have content related to the topic were excluded.

In the third stage, data were extracted from selected articles, guided by the instrument that contained information such as author, year, country, study design, sample, perinatal period, occurrences, instruments and their scores ${ }^{(12)}$ and classification of levels of scientific evidence based on the Melnyk and FineoutOverholt model ${ }^{(14)}$ (Chart 2).

Chart 2 - Characterization of studies included according to authorship, design, sample, perinatal period assessed, occurrences, instruments, scores, and level of evidence, 2019

\begin{tabular}{|c|c|c|c|c|c|c|}
\hline Author, year, country & Design & Sample & Perinatal period & Occurrence & $\begin{array}{c}\text { Instruments } \\
\text { and scores }\end{array}$ & $\begin{array}{l}\text { Level of } \\
\text { Evidence }\end{array}$ \\
\hline \multirow[b]{2}{*}{$\begin{array}{l}\text { Alvarenga, Frizzo, } \\
2017, \text { Brazil }^{(16)}\end{array}$} & \multirow[b]{2}{*}{ Cohort } & \multirow[b]{2}{*}{79} & $3^{\text {rd }}$ gestational trimester & $63 \% \mathrm{CMD} \square$ & $S R Q-20 \geq 8$ & \\
\hline & & & 30 days after birth & $\begin{array}{l}30.4 \% \text { MIDS } \\
16.5 \% \text { MDS } \\
3.8 \% \text { SDS }\end{array}$ & $\begin{array}{c}\text { BDI-I } \\
12-18 \text { MIDS } \\
20-35 \text { MDS } \\
\geq 36 \text { SDS }\end{array}$ & III \\
\hline \multirow{2}{*}{$\begin{array}{l}\text { Aryal, et al, 2018, } \\
\text { Nepal(17) }\end{array}$} & \multirow{2}{*}{$\begin{array}{l}\text { Cross- } \\
\text { sectional }\end{array}$} & $164 \square$ & Gestation $\square$ & $\begin{array}{c}21 \%(95 \% \mathrm{Cl} 15,7-28.3) \mathrm{AS} \\
24 \%(95 \% \mathrm{Cl} 17.8-31.0) \mathrm{DS} \\
14.6 \%(95 \% \mathrm{Cl}: 10.0-21.0) \mathrm{CMD}\end{array}$ & \multirow{2}{*}{$\begin{array}{l}\text { HSCL } 25 \\
\geq 17.5 \text { AS } \\
\geq 24.5 \text { DS }\end{array}$} & \multirow[b]{2}{*}{ V } \\
\hline & & 567 & $\begin{array}{l}\text { After birth (up to } 12 \\
\text { months) }\end{array}$ & $\begin{array}{c}19 \%(95 \% \mathrm{Cl} 15.7-2.1) \mathrm{AS} \\
15 \%(95 \% \mathrm{Cl} 12.4-18.4) \mathrm{DS} \\
11.5 \%(95 \% \mathrm{Cl}: 9.1-14.4) \mathrm{CMD}\end{array}$ & & \\
\hline $\begin{array}{l}\text { Bekele, et al, 2017, } \\
\text { Ethiopia }^{(18)}\end{array}$ & $\begin{array}{c}\text { Cross- } \\
\text { sectional }\end{array}$ & 753 & $3^{\text {rd }}$ gestational trimester & $26.2 \%(95 \% \mathrm{Cl} 23.04-29.36) \mathrm{CMD}$ & $S R Q-20 \geq 6$ & $\mathrm{~V}$ \\
\hline $\begin{array}{l}\text { Clarke, et al, 2014, } \\
\text { Nepal(19) }\end{array}$ & $\begin{array}{c}\text { Cross- } \\
\text { sectional }\end{array}$ & 9.078 & 41 days after birth & $9.8 \% \mathrm{CMD}$ & GHQ-12 $\geq 6$ & V \\
\hline \multirow{2}{*}{$\begin{array}{l}\text { Estrin, et al, 2019, } \\
\text { England }^{(20)}\end{array}$} & \multirow{2}{*}{$\begin{array}{l}\text { Cross- } \\
\text { sectional }\end{array}$} & $488<25$ years old $\square$ & $1^{\text {st }}$ ectational trimecter & $\begin{array}{c}45.1 \%(95 \% \mathrm{Cl} 23.5-68,7) \\
\mathrm{CMD}<25 \text { years old }\end{array}$ & \multirow{2}{*}{$\begin{array}{l}\text { SCID-I- } \\
\text { Research } \\
\text { Version* }\end{array}$} & \multirow[b]{2}{*}{ V } \\
\hline & & $57 \geq 25$ years old & r gestationar timinester & $\begin{array}{c}15.5 \%(95 \% \mathrm{Cl} 12.0-19.8) \\
\text { CMD } \geq 25 \text { years old }\end{array}$ & & \\
\hline $\begin{array}{l}\text { Filha, et al, 2016, } \\
\text { Brazil(10) }^{(10)}\end{array}$ & $\begin{array}{c}\text { Cross- } \\
\text { sectional }\end{array}$ & 23.894 & 12 months after birth & $26.3 \% \mathrm{DS} \square$ & $E P D S \geq 13$ & v \\
\hline \multirow{3}{*}{$\begin{array}{l}\text { Hain, et al, 2016, } \\
\text { Germany }^{(21)}\end{array}$} & \multirow{3}{*}{ Cohort } & 297 & $3^{\text {rd }}$ gestational trimester & $10 \% \mathrm{DS} \square$ & \multirow{3}{*}{$\begin{array}{l}\text { BDI-V } \\
\text { EPDS }^{* *}\end{array}$} & \multirow{3}{*}{ III } \\
\hline & & 278 & 6 weeks after birth & $10 \% \mathrm{DS} \square$ & & \\
\hline & & 266 & 20 weeks after birth & $6 \% \mathrm{DS} \square$ & & \\
\hline $\begin{array}{l}\text { Lucchese, et al, 2017, } \\
\text { Brazil }^{(22)}\end{array}$ & $\begin{array}{c}\text { Cross- } \\
\text { sectional }\end{array}$ & 229 & $2^{\text {nd }}$ gestational trimester & $51.7 \%$ (95\% Cl 51.7-62.6) CMD & $S R Q-20 \geq 7$ & V \\
\hline \multirow{2}{*}{$\begin{array}{l}\text { MacLean, et al, 2015, } \\
\text { Brazil(23) }^{(23)}\end{array}$} & \multirow[t]{2}{*}{ Cohort } & 831 & $\begin{array}{l}\text { Between 20-30 } \\
\text { gestational weeks }\end{array}$ & $36.2 \% \mathrm{CMD} \square$ & \multirow[t]{2}{*}{$S R Q-20 \geq 8$} & \multirow{2}{*}{ III } \\
\hline & & 219 & 11 months after birth & NPR & & \\
\hline $\begin{array}{l}\text { Reichenheim, et al, } \\
2014, \text { Brazil }^{(24)}\end{array}$ & $\begin{array}{c}\text { Cross- } \\
\text { sectional }\end{array}$ & 810 & 5 months after birth & $25.4 \%(95 \% \mathrm{Cl} 22.4-28.4) \mathrm{CMD}$ & SRQ-20 $\geq 7$ & V \\
\hline \multirow{4}{*}{$\begin{array}{l}\text { Tran, 2014, et al, } \\
\text { Vietnan (25) }\end{array}$} & \multirow{4}{*}{ Cohort } & \multirow{4}{*}{378} & 12-20 gestational weeks & $38.9 \% \mathrm{CMD} \square$ & \multirow{4}{*}{ EPDS-V $\geq 4$} & \multirow{4}{*}{ III } \\
\hline & & & $\geq 32$ gestational weeks & $28 \% \mathrm{CMD} \square$ & & \\
\hline & & & 8 weeks after birth & $10.8 \% \mathrm{CMD} \square$ & & \\
\hline & & & 6 months after birth & $12.4 \% \mathrm{CMD} \square$ & & \\
\hline \multirow{2}{*}{$\begin{array}{l}\text { Usuda, et al, 2016, } \\
\operatorname{Japan}^{(26)}\end{array}$} & \multirow{2}{*}{$\begin{array}{c}\text { Cross- } \\
\text { sectional }\end{array}$} & \multirow{2}{*}{177} & \multirow{2}{*}{ 12-24 gestational weeks } & $1.1 \%(95 \% \mathrm{Cl} 0.00-0.04) \mathrm{DS}$ & EPDS $\geq 9$ & \multirow[b]{2}{*}{ V } \\
\hline & & & & $6.2 \%(95 \% \mathrm{Cl} 0.03-0.11) \mathrm{CMD}$ & $\mathrm{MINI}^{*}$ & \\
\hline \multirow{4}{*}{$\begin{array}{l}\text { Wikman, et al, 2019, } \\
\text { Sweden (27) }\end{array}$} & \multirow{4}{*}{ Cohort } & \multirow{4}{*}{1.491} & $\begin{array}{c}\text { Between 17-32 } \\
\text { gestational weeks }\end{array}$ & $8.5 \% \mathrm{DS} \square$ & & \\
\hline & & & 6 weeks after birth & $10.9 \% \mathrm{DS} \square$ & $\geq 13$ gestation & \\
\hline & & & 6 months after birth & $5.4 \% \mathrm{DS} \square$ & birth & III \\
\hline & & & All trajectories $\square$ & $14.6 \% \mathrm{PDS} \square$ & & \\
\hline
\end{tabular}

Note: SRQ-20 - Self-Reporting Questionnaire; BDI-I - Beck Depression Inventory l; HSCL 25 - Hopkins Symptom Checklist 25; GHQ-12 - 12-item General Health Questionnaire; SCID-I-Research Version - Structured Clinical Interview for DSM-IV-TR Axis I Disorders; EPDS - Edinburgh Postnatal Depression Scale; BDI-V - Beck Depression Inventory; GHQ-28 - 28-item version of the General Health Questionnaire; MINI - The Mini-International Neuropsychiatric Interview; AS - Anxious Symptom; DS - Depressive Symptom; MIDS-Mild Depressive Symptom; MDS - Moderate Depressive Symptom; SDS - Severe Depressive Symptom; PDS - Persistent Depressive Symptom; CMD - Common Mental Disorder; NPR - No prevalence for the period and the persistence of CMD for both periods; $\square$ Total study participants: $731^{(17)}$ and 545(20); $\square$ Did not describe the gestational trimester; $\square$ Investigated the trajectory of perinatal depressive symptoms, from 17-32 weeks of gestation to 6 months after birth $^{(27)} ; \square$ Confidence interval not available. *Diagnostic instrument, without scoring; **Score not described in the study. 
Scores are defined by the sum of answers of questions of a specific screening instrument; instruments have different ways of answering questions, which can be dichotomous (yes/no) or ordinal, with a range from 0 to 3 , for instance. The final sum of answers classified whether the interviewee had one of the illnesses or not ${ }^{(15)}$. The classification of level of evidence ${ }^{(14)}$ is a hierarchical system divided into six levels: I - Evidence from at least one well-designed randomized controlled clinical trial; II - Evidence obtained from well-designed clinical trials without randomization; III - Evidence obtained from well-designed casecontrol or cohort studies; IV - Evidence from systematic reviews of descriptive and qualitative studies; $V$ - Evidence from a single descriptive or qualitative study; VI - Evidence from the opinion of authorities and/or reports of expert committees.

In the fourth, fifth and sixth stages, titles and abstracts were read, applying the eligibility criteria in order to refine the sample by including those who responded to the objective of this LIR. Sequentially, each selected article was read in full, subsidizing reflections about the studied phenomenon and organization of articles for data collection. Finally, analysis was carried out critically, identifying subjects related to each article, different methodologies, samples, and data collection.

An initial search carried out by two independent reviewers with a standardized protocol for using descriptors and crossreferencing has found 198 articles. After applying the inclusion and exclusion criteria, there were 108 articles. After reading titles and abstracts, 32 were analyzed, 19 of which were excluded and finally 13 were included in this qualitative analysis (Figure 1).

All studies were analyzed thoroughly, aiming to answer the guiding question of this ILR considering the ethical aspects and respecting the authorship of ideas, concepts and definitions.

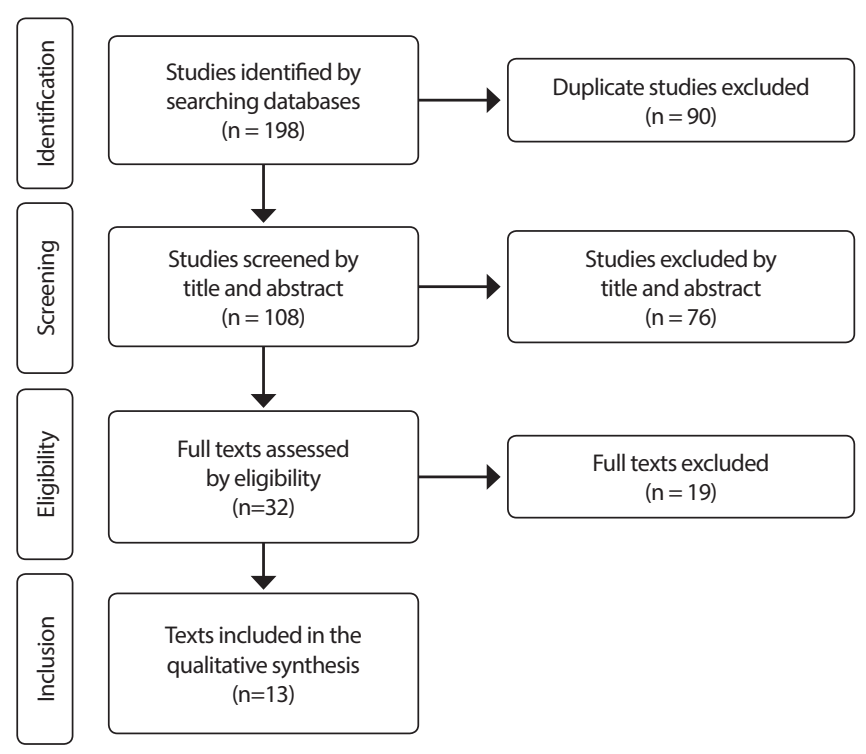

Figure 1 - Flowchart with representation of eligibility and inclusion of articles in the selection of studies

\section{RESULTS}

A total of 13 articles were included in this ILR, 30.8\% of which were indexed in CINAHL; $15.4 \%$ in Embase; $15.4 \%$ in LILACS; $30.8 \%$ in PubMed/MEDLINE; and 7.6\% in PsycINFO. Most studies were conducted in Brazil $(30.8 \%)^{(10,16,22-23)}$, with cross-sectional design $(61.5 \%)^{(10,18-20,22,24,26)}$, and most of them were $(23 \%)$ carried out in $2016^{(10,21,26)}$ and $2017^{(16,18,22)}$. Concerning the perinatal period, most were performed during pregnancy and after birth ${ }^{(16-17,21,23,25-27)}$ and the others only during pregnancy ${ }^{(18,20,22)}$ or after birth ${ }^{(10,19,24)}$.

The most used screening instruments were the Self-Reporting Questionnaire-20 (SRQ-20) and the Edinburgh Postnatal Depression Scale (EPDS). The SRQ-20 was used to assess CMD in pregnancy ${ }^{(16,18,22-23)}$, and the EPDS was used to screen postpartum $D^{(10,21,26)}$. The cut-off point of the SRQ-20 score to classify the CMD adopted ranged between $\geq 6$ and $\geq 8$; and for the EPDS, it ranged between $\geq 4$ and $\geq 13$.

The highest prevalence of gestational CMD was found in two studies carried out in Brazil by Alvarenga et al. ${ }^{(16)}$ (63\%) and by Lucchese et al. ${ }^{(22)}(51.7 \%)$; the lowest prevalence (1.1\%) was found in a study conducted by Usuda et al. ${ }^{(26)}$ in Japan. The highest occurrence of postpartum CMD was also registered in a Brazilian study $(25.4 \%)^{(24)}$; and the lowest prevalence was registered in Nepal $(9.8 \%)^{(19)}$. The highest prevalence of postnatal DS was found in a Brazilian study ${ }^{(16)}(30.4 \%)$ and the lowest in Sweden ${ }^{(27)}$ (5.4\%). None of the studies included in the qualitative analysis presented incidence data for the outcomes assessed.

There were conceptual differences about CMD between that adopted by $\mathrm{WHO}^{(4)}$ and two of the studies analyzed. A study carried out in England ${ }^{(20)}$ considered CMD from a DS set to disorders related to stressful traumas such as post-traumatic stress disorder. A study carried out in Japan ${ }^{(26)}$ considered CMD only DS. Given the conceptual difference, even though a screening instrument was used, there was a difference in outcomes. In England, researchers used the SCID-I-Research Version; and the Japanese study used the EPDS.

Unplanned pregnancy ${ }^{(18,22)}$, history of $\mathrm{MD}^{(18,26)}$ and living without a partner ${ }^{(20,22)}$ were frequently reported as risk factors associated with CMD during pregnancy. The same occurred with obstetric problems in current gestation $^{(18)}$, gestational age $\geq 23$ weeks $^{(22)}$, having suffered abuse in life (intimate partner violence, sexual violence, physical or sexual abuse in childhood)(20), experience traumatic interpersonal history, and pressure to have a child(26).

Low socioeconomic status ${ }^{(19,24)}$, stressors during pregnancy (illnesses, losses due to death), intimate partner violence (physical and verbal) (24), gender inequality or low reproductive health, food insecurity ${ }^{(19)}$ were associated to postpartum CMD, reported frequently. The predictors most associated with postpartum DS were unplanned pregnancies ${ }^{(10,17)}$, alcohol ${ }^{(10)}$ and tobacco use ${ }^{(17)}$. DS was also associated with low socioeconomic status ${ }^{(10)}$, agriculture and farming as a source of income ${ }^{(17)}$, history of mental disorder, and multiparity ${ }^{(10)}$.

Among the studies carried out during pregnancy and after birth, tobacco use was associated with $\mathrm{CMD}^{(23)}$ and persistent DS ${ }^{(27)}$. Sleep disturbance was associated with persistent CMD, and intimate partner violence, childhood trauma, being a single mother and low partner support with the child was associated with persistent DS ${ }^{(27)}$.

Concerning the association between CMD in pregnancy with DS after birth, a study conducted in Brazil has found a direct relationship between them. Each increase in the SRQ-20 score 
by one was associated with an increase of 0.72 in the BDI-I score, adjusted for covariates. The investigated model was responsible for explaining about $13 \%(p=.004)$ of the BDI-I variation ${ }^{(16)}$.

Most of studies were carried out at community-based ${ }^{(17,19,25)}$ hospitals ${ }^{(10,16,18,20-21,26-27)}$. A smaller part was carried out at $\mathrm{PHC}^{(23-24)}$ and at specialized women's health care services ${ }^{(22)}$.

The data collection teams were quite diverse, from undergraduate psychology ${ }^{(16)}$ and nursing students ${ }^{(22)}$ to specialized professionals such as experienced psychiatric nurses ${ }^{(18)}$, psychiatrists and psychologists ${ }^{(26)}$. Data were also collected by health professionals, without specifying the professional category, women ${ }^{(24)}$, health professionals and assistant researchers, not specialized in mental health ${ }^{(17,23)}$.

\section{DISCUSSION}

It was observed a quite different universe of methodologies, instruments, cut-off points of scores used. Although the same instrument was adopted in different regions of the same country, it was applied at different perinatal times and with different scores. This is the case of the SRQ-20, widely used in Brazil, and the EPDS, the most used postpartum depression screening scale worldwide ${ }^{(28-29)}$.

The lowest prevalence using the SRQ-20 was $25.4 \%$ to screen postpartum CMD using a score $\geq 7^{(24)}$; and the highest prevalence was $63 \%$, with a score $\geq 8$, gestational $C D^{(16)}$. With the EPDS the differences between the lowest and the highest prevalence and scores adopted were more significant (1.1\%), with a score $\geq 9$, DS during pregnancy ${ }^{(26)}$, and $26.3 \%$, with a score $\geq 13$, DS after birth ${ }^{(10)}$.

The different conceptualizations of CMD among the studies included in this review ${ }^{(20,26)}$ in relation to that defined by the $\mathrm{WHO}^{(3,4)}$ corroborate the complexity of compiling results and understanding the phenomenon studied. All of these differences exist due to the diversity of cultural and social scenarios in which studies are carried out, which often happens within the same country, such as Brazil, which has continental dimensions. This variation of score for screening, for instance, directly interferes with the results found in each study ${ }^{(20,26)}$.

The SRQ-20 is a screening instrument that is quick and easy to apply, easy to understand by patients of all levels of education, open access, low cost, without the requirement of a clinical interviewer or expert, originally developed for $\mathrm{PHC}^{(30,31)}$. Proving to be useful both for the clinic and for research, in population-based studies in PHC, which aim to identify non-psychotic psychiatric cases $^{(3)}$. The EPDS is also easy to apply and well established in scientific literature, with indication for use in the clinic and in research by nonexpert interviewers ${ }^{(28,32)}$.

Using these instruments is a valuable strategy for estimating magnitude and screening the occurrences of interest at an appropriate time in health services. The SRQ-20 and the EPDS can be used in the perinatal period independently or in combination, which make them necessary tools for Brazilian and other developing countries.

Studies warn of the high prevalence of the investigated outcomes and the frequent association between factors and outcomes. Prevalence ranged from $1.1 \%$ to $10 \%$ in Japan ${ }^{(26)}$ and Germany in studies in high-income countries included in this ILR ${ }^{(21)}$. In both the Japanese and German studies, screening was performed in a private hospital, with participants with a high level of education.
In low and middle income countries prevalence was $26.2 \%$ in Nepal ${ }^{(19)}$ and 63\% in Brazil(16). Nepalese participants lived in a rural community and Brazilians were seen at a public hospital. Our results confirm the importance of the already established predictors (history of childhood abuse, women raped by an intimate partner, low maternal education, low socioeconomic status, low social support and history of MD) as they are characterized as risk factors ${ }^{(9,33-34)}$, signaling the importance of new predictors or those still poorly studied (food insecurity, sleep disturbance, gender inequality or poor reproductive health, pressure to have a child) $)^{(23,26-27)}$.

The direct relationship between CMD during pregnancy with DS after birth found in a study conducted in Brazil(16) shows a connection between the events and the existence of a possible causal relationship. However, further investigations are necessary, considering the level of exposure of the population to events.

It was observed that the studies were carried out in different scenarios, services and level of health care. Despite this heterogeneity, research in hospitals, clinics and specialized services is valid for a better understanding of psychological distress throughout the perinatal cycle. Population-based studies carried out at PHC are important sources of information, especially to develop preventive strategies. Moreover, studies carried out in other places help building care strategies, and screening such conditions should be encouraged at the most diverse levels of health care.

Data collection was carried out by several actors, from undergraduate students to experts. All authors were careful in relation to the gender of interviewees, women, when addressing violence experienced by them ${ }^{(24)}$. This diversity demonstrates the importance of screening by nonexpert professionals in order to expand the reach of women assisted in PHC services.

Despite the importance of early detection of perinatal MD in PHC, prenatal care is still focused on physiological changes in pregnancy. This shows, in Brazil, a gap in the assistance protocols developed by the Ministry of Health for maternal life ${ }^{(6)}$. Furthermore, professionals are unaware of the methods of screening and interventions due to lack of training in perinatal mental health, given the lack of prioritization of this dimension in undergraduate courses ${ }^{(35)}$.

Therefore, it is recommended to use interventions that promote maternal well-being in prenatal care, namely: early identification of risk factors; establishment of a relationship of trust between professional and user; preparation to perform maternal role; identification of the social support network; encouragement of the partner's involvement in the pregnancy-puerperal cycle; and conducting home visits, especially after birth ${ }^{(36)}$. There are also more specific interventions, such as psychotherapy and multidisciplinary psychosocial. Psychotherapy is aimed at women without pregnancy risk MD aiming to reduce such risk after birth. Multidisciplinary psychosocial is for women with positive results for MD screening, at some perinatal time, aiming at stabilizing the clinical picture ${ }^{(37-38)}$. However, they need to be extensively studied and adapted nation-wide.

Early identification of perinatal MD from the first prenatal consultation is necessary and feasible. This means addressing all pregnant women and turning their attention to those who have multiple risk factors. Women do not readily admit to being sick due to stigmas related to $M D$ and the feeling that they are failing as mothers ${ }^{(38-39)}$. 
It is recommended that Brazil, as well as for low and middle income countries, expand mental health care through $\mathrm{PHC}$ performed by health professionals not specialized in mental health ${ }^{(40)}$.

\section{Study limitations}

Included studies available electronically, in certain databases, in English, Portuguese and Spanish, and cohort and cross-sectional observational studies, mostly with level of evidence $V$ were considered a limitation of this study. These choices may cause omission of studies including other criteria inclusion criteria related to the descriptors used.

\section{Contributions to nursing, health, and public policies}

This study can contribute with dissemination to nonexpert health professionals about the importance of actions to detect perinatal MD, with emphasis on presentation of instruments for screening CMD and perinatal DS validated for reality and open access. There is a need for screening for CMD and DS since first prenatal consultation by creating and implementing a care protocol for this purpose, with a view to preventing damage to maternal and child mental health.

\section{CONCLUSION}

There is a very heterogeneous population, methodological, linguistic and cultural universe and difficulty compiling the results around a single estimate of the magnitude of the problems studied and the outcomes assessed. Moreover, in the national reality, there is a lack of protocols for these morbidities in PHC and a lack of professional training in perinatal mental health.

Despite the difficulty in homogenizing the results, high frequencies were found for perinatal MD. High frequencies of MD in studies carried out in populations in Brazil stood out, demonstrating that $\mathrm{MD}$ is common and requires due attention in prenatal care.

Given the complexity and magnitude observed about the problem in reality, perinatal mental health demands special attention from researchers and health professionals. Research is needed to determine paths for professional training and establish care protocols considering the Brazilian reality.

\section{FUNDING}

This study received financial support from two Brazilian public agencies: 1) Ministry of Health - Funding of the Research Program for SUS (Programa Pesquisa para o SUS) - FAPAC/SESACRE/PPSUS $\mathrm{MoH} / \mathrm{CNPq}$. Notice PPSUS 001/2015; 2) Ministry of Education Doctoral scholarship from the Coordination for the Improvement of Higher Education (Coordenação de Aperfeiçoamento Pessoal de Nível Superior, abbreviated CAPES). Processes 1579109/2016 and $1764752 / 2018$.

\section{ACKNOWLEDGMENTS}

We would like to thank Marília Ignácio de Espíndola for exchanging knowledge in building and writing this review and to Juliana Akie Takahashi for assistance in refining the search strategies.

\section{REFERENCES}

1. Associação Americana de Psiquiatria. Manual diagnóstico e estatístico de transtornos mentais. 5. ed. Nascimento MIC, et al, tradutores. Porto Alegre: Artmed; 2014. 948p.

2. Serati M, Carnevali G. Perinatal depression. In: Altamura AC, Brambilla P, editors. Clinical cases in psychiatry: integrating translational neuroscience approaches. Springer International Publishing AC, part of Spring Natura. 2019;155-76. doi: 10.1007/978-3-319-91557-9

3. Gonçalves DM, Stein AT, Kapczinski F. Avaliação de desempenho do Self-Reporting Questionnaire como instrumento de rastreamento psiquiátrico: um estudo comparativo com o Structured Clinical Interview for DSM-IV-TR. Cad Saude Publica. 2008;24(2):380-90. doi: 10.1590/S0102-311X2008000200017

4. World Health Organization (WHO). Depression and other common mental disorders: global health estimates. Geneve: WHO; 2017. 24p.

5. Organização Mundial da Saúde (OMS). Classificação de Transtornos Mentais e de Comportamento. diretrizes clínicas e diretrizes diagnósticas. 10. ed. Porto Alegre: Artmed; 1993. 352p.

6. Ministério da Saúde (BR). Secretaria de Atenção à Saúde. Departamento de Atenção Básica. Atenção ao Pré-Natal de Baixo Risco. Brasília: Editora do Ministério da Saúde, 2013. [cited 2019 Jun 10]. Available from: http://bvsms.saude.gov.br/bvs/publicacoes/cadernos_atencao_ basica_32_prenatal.pdf

7. World Health Organization (WHO). Maternal mental health and child health and development in low and middle income countries: report of the meeting held in Geneva, Switzerland 30 January - 1 February, 2008 [Internet]. 2008[cited 2019 Jul 20]; Geneve: WHO. Available from: https://www.who.int/mental_health/prevention/suicide/mmh_jan08_meeting_report.pdf

8. Goodman JH. Postpartum depression beyond the early postpartum period. J Ob Gynecol Neonatal Nurs. 2005;33(4):410-420. doi: $10.1177 / 0884217504266915$

9. Lobato G, Moraes CL, Reichenheim ME. Magnitude da depressão pós-parto no Brasil: uma revisão sistemática. Rev Bras Saúde Matern Infant. 2011;11(4):369-79. doi: 10.1590/S1519-38292011000400003

10. Theme Filha MM, Ayers S, Gama SGN, Leal MDC. Factors associated with postpartum depressive symptomatology in Brazil: the Birth in Brazil National Research Study, 2011/2012. J Affect Disord. 2016;194:159-67. doi: 10.1016/j.jad.2016.01.020 
11. Guintivano J, Manuck T, Meltzer-Brody S. Predictors of postpartum depression: a comprehensive review of the last decade of evidence. Clin Obstet Gynecol. 2018;61(3):591-603. doi: 10.1097/GRF.0000000000000368

12. Mendes KDS, Silveira RCCP, Galvão CM. Revisão integrativa: método de pesquisa para a incorporação de evidências na saúde e na enfermagem. Texto Contexto Enferm. 2008;17(4):758-64. doi: 10.1590/s0104-07072008000400018

13. Lockwood C, Porritt K, Munn Z, Rittenmeyer L, Salmond S, Bjerrum M, et al. Systematic reviews of qualitative evidence. In: Aromataris E, Munn Z, editors. JBI Reviewer's Manual [Internet]. 2017 [cited 2020 Apr 22];23-71. Available from: https://wiki.joannabriggs.org/display/ MANUAL/JBI+Reviewer\%27s+Manual

14. Melnyk BM, Fineout-Overholt E. Making the Case for Evidence-Bd Pratice and Cultiving a Spirit of Inquiry. In: Melnyk BM, Fineout-Overholt E, editors. Evidence-based practice in nursing and healthcare: a guide to best practice. 3rd ed. Philadelphia: Lippincot Williams \& Wilkins; 2015. pp. 3-23.

15. Wang Y-P. Entrevistas diagnósticas e instrumentos de triagem. In: Gorenstein C, Wang Y-P, Hugenrbühler I, editors. Instrumentos de avaliação em saúde mental. Porto Alegre: Artmed; 2016. pp. 59-86.

16. Alvarenga P, Frizzo GB. Stressful life events and women's mental health during pregnancy and postpartum period. Paidéia (Ribeirão Preto). 2017;27(66):51-59. doi: 10.1590/1982-43272766201707

17. Aryal KK, Alvik A, Thapa N, Mehata S, Roka T, Thapa P, et al. Anxiety and depression among pregnant women and mothers of children under one year in Sindupalchowk District, Nepal. J Nepal Health Res Counc. 2018;16(2):195-204.

18. Bekele D, Worku A, Wondimagegn D. Prevalence and associated factors of mental distress during pregnancy among antenatal care attendees at Saint Paul's Hospital, Addis Ababa. Ob Gynecol Int J. 2017;7(6):1-7. doi: 10.15406/ogij.2017.07.00269

19. Clarke K, Saville N, Shrestha B, Costello A, King M, Manandhar D, et al. Predictors of psychological distress among postnatal mothers in rural Nepal: a cross-sectional community-based study. J Affect Disord. 2014;156(100):76-86. doi: 10.1016/j.jad.2013.11.018.

20. Estrin GL, Ryan EG, Trevillion K, Demilew J, Bick D, Pickles A, Howard LM. Young pregnant women and risk for mental disorders: findings from an early pregnancy cohort. BJ Psych Open. 2019;5(2):e21,1-7. doi: 10.1192/bjo.2019.6

21. Hain S, Oddo-Sommerfeld S, Bahlmann F, Louwen F, Schermelleh-Engel K. Risk and protective factors for antepartum and postpartum depression: a prospective study. J Psychosom Ob Gynecol. 2016;37(4):119-29. doi: 10.1080/0167482X.2016.1197904

22. Lucchese R, Simões ND, Monteiro LHB, Vera I, Fernandes IL, Castro PA, et al. Factors associated with the probability of common mental disorders in pregnant women: a cross-sectional study. Esc Anna Nery. 2017;21(3):e20160094. doi: 10.1590/2177-9465-ean-2016-0094

23. Maclean JV, Faisal-Cury A, Chan Y, Menezes PR, Winters A, Joseph R, et al . The relationship between sleep disturbance in pregnancy and persistent common mental disorder in the perinatal period (sleep disturbance and persistent CMD). J Ment Health. 2015;24(6):375-378. doi: 10.3109/09638237.2015.1036969

24. Reichenheim ME, Moraes CL, Lopes CS, Lobato G. The role of intimate partner violence and other health-related social factors on postpartum common mental disorders: a survey-based structural equation modeling analysis. BMC Public Health. 2014;14:427. doi:10.1186/1471-2458-14-427

25. Tran TD, Biggs BA, Tran T, Simpson JA, Mello MC, Hanieh S, et al. Perinatal common mental disorders among women and the social and emotional development of their infants in rural Vietnam. J Affect Disord. 2014;160:104-112. doi: 10.1016/j.jad.2013.12.034

26. Usuda K, Nishi D, Makino M, Tachimori H, Matsuoka Y, Sano Y, et al. Erratum to: prevalence and related factors of common mental disorders during pregnancy in Japan: a cross-sectional study. Biopsychosoc Med. 2016;10(1):26. doi: 10.1186/s13030-016-0077-1

27. Wikman A, Axfors C, lliadis S, Cox J, Fransson E, Skalkidou A. Characteristics of women with different perinatal depression trajectories. J Neurosci Res. 2019;00:1-15. doi:10.1002/jnr.24390

28. Santos IS, Matijasevich A, Tavares BF, Barros AJD, Botelho IP, Lapolli C, et al. Validation of the Edinburgh Postnatal Depression Scale (EPDS) in a sample of mothers from the 2004 Pelotas Birth Cohort Study. Cad Saúde Pública. 2007;23(11):2577-88. doi: 10.1590/S0102-311X2007001100005

29. Cox J. Use and misuse of the Edinburgh Postnatal Depression Scale (EPDS): a ten point 'survival analysis'. Arch Womens Ment Health. 2017;20(6):789-790. doi: 10.1007/s00737-017-0789-7

30. World Health Organization (WHO). Organization of mental health services in developing countries: sixteenth report of the WHO Expert Committee on Mental Health. Meeting held in Geneva from 22 to 28 October, 1974 [Internet]. 1975[cited 2019 Jul 20]. Geneve: WHO. Available from: https://apps.who.int/iris/handle/10665/38212

31. Harding TW, Arango MV, Baltazar J, Climent CE, Ibrahim HH, Ladrido-lgnacio L, et al. Mental disorders in primary health care: a study of their frequency and diagnosis in four developing countries. Psychol Med. 1980;10(2):231-241. doi: 10.1017/S0033291700043993

32. Cox J, Holden JM, Sagovsky R. Detection of postnatal depression. Development of the 10-item Edinburgh Postnatal Depression Scale. Br J Psychiatry. 198;150(6):7782-86. doi: 10.1192/bjp.150.6.782

33. Fisher J, Mello MC, Patel V, Rahman A, Tran T, Holton S, et al. Prevalence and determinants of common perinatal mental disorders in women in low-and lower-middle-income countries: a systematic review. Bull World Health Organ. 2012;90(2):139-49. doi: 10.2471/BLT.11.091850

34. Gelaye B, Rondon MB, Araya R, Williams MA. Epidemiology of maternal depression, risk factors, and child outcomes in low-income and middle-income countries. Lancet Psychiatr. 2016;3(10):973-82. doi: 10.1016/S2215-0366(16)30284-X

35. Meira BM, Pereira APS, Silveira MFA, Gualda DMR, Santos Jr HPO. Desafios para profissionais da atenção primária no cuidado à mulher com depressão pós-parto. Texto Contexto Enferm. 2015;24(3):706-12. doi: 10.1590/0104-0707201500049-14 
36. Guerra M, Braga M, Quelhas I, Silva R. Promoção da saúde mental na gravidez e no pós-parto. Rev Port Enferm Saúde Mental [Internet]. 2014 [cited 2019 Oct 10];(no.spe1):117-24. Available from: http://www.scielo.mec.pt/pdf/rpesm/nspe1/nspe1a19.pdf

37. Cauli G, lapichino E, Rucci P, Quartieri Bollani M, Marconi AM, Bassi M, et al. Promoting the well-being of mothers with multidisciplinary psychosocial interventions in the perinatal period. J Affect Disord. 2019;246:148-56. doi: 10.1016/j.jad.2018.12.028

38. Lara-Cinisomo S, Clark CT, Wood J. Increasing diagnosis and treatment of perinatal depression in Latinas and African American women: addressing stigma is not enough. Womens Health Issues. 2018;28(3):201-4. doi: 10.1016/j.physbeh.2017.03.040

39. Buist A. Perinatal mental health: Identifying problems and managing medications. Aust Fam Physician. 2014 [cited 2019 Sep 20];43(4):182-5. Avaliable from: https://www.racgp.org.au/afp/2014/april/perinatal-mental-health/

40. World Health Organization. mhGAP intervention guide for mental, neurological and substance use disorders in non-specialized health settings: mental health Gap Action Programme (mhGAP) - version 2.0. Geneva: WHO. 2016 [cited 2019 Aug 15]. Available from: https:// www.who.int/mental_health/mhgap/mhGAP_intervention_guide_02/en/ 